\title{
Effect of crude extracts of leaves of Smallanthus sonchifolius (yacon) on glycemia in diabetic rats
}

\author{
Silmara Baroni', Fumie Suzuki-Kemmelmeier², Silvana Martins Caparroz-Assef', \\ Roberto Kenji Nakamura Cuman', Ciomar Aparecida Bersani-Amado ${ }^{*}$
}

\begin{abstract}
${ }^{1}$ Laboratory of Inflammation, Department of Pharmacy and Pharmacology, State University of Maringá, ${ }^{2}$ Laboratory of Hepatic Metabolism, Department of Biochemistry, State University of Maringá
\end{abstract}

*Correspondence:

Ciomar A. Bersani-Amado

Department of Pharmacy and

Pharmacology

University of Maringá

Avenida Colombo, 5790

87020-900 - Maringá - PR, Brazil.

E-mail: cabamado@uem.br.
The present study investigated the effect of crude extracts from yacon leaves, obtained by aqueous cold $\left(Y_{C}\right)$ or hot $\left(Y_{H}\right)$ extraction, or hydroethanolic extraction $\left(Y_{E}\right)$, on glycemia of the diabetic (induced by streptozotocine, $50 \mathrm{mg} / \mathrm{kg}$, ip) and nondiabetic rats. The animals were treated orally with the extracts (400 mg/kg) or water for 3, 7, 10, and 14 days. After this period, the animals were anesthetized and blood samples were collected for measurement of plasmatic glucose and creatinine and activity of the enzymes (AST, ALT, ALP). Also were evaluated the consumption of food, water, urine volume, body weight of the animals and $L D_{50}$ of $Y_{E}$. Treatment with $Y_{E}$ for 14 days reduced glycemia in diabetic and nondiabetic animals. No similar reduction was observed in animals treated with $Y_{C}$ or $Y_{H}$ Additionally, $Y_{E}$ restored the activity of the plasmatic enzymes that were altered, and improved weight gain in the diabetic animals. These results showed that the effectiveness of the yacon extracts is related to the method of preparation and to the time of treatment. The effect of $Y_{E}$ on glycemia in diabetic rats is not related to reduction of food intake or to interference of the extract with intestinal absorption of carbohydrates.
Uniterms

- Aqueous extract

- Antihyperglycemic

- Diabetes Mellitus

- Hydro-ethanolic extract

- Smallanthus sonchifolius

\section{INTRODUCTION}

Diabetes Mellitus (DM) is a chronic metabolic disorder, characterized by a state of insulin deficiency that leads to a rise in glycemia (Gupta et al., 2005), initially involving changes in carbohydrate metabolism and secondarily of lipids and proteins (Fontes, 2002; Negri, 2005).

The most common symptoms observed in type I diabetes patients are polydipsy, polyuria, glycosuria, weakness with no apparent cause, and slow healing of wounds (Fontes, 2002). The levels of glycemia and insulinemia must be controlled in order to avoid later complications of diabetes, such as atherosclerosis, hypertension, hypertriglyceridemia, hypercholesterolemia, myocardial infarction, ischemic attacks, impotence, retinopathy, nephropathy, etc (Stadler et al., 2003).

As yet there are no effective therapies to cure diabetes (Maiti et al., 2004). Many hypoglycemiant agents, such as the biguanides and sulfonylureas, are used alone or together with insulin to treat this disease. However, these medications can cause serious side effects (Hwang et al., 
2005), motivating a search for safer, more efficacious agents to control diabetes.

In recent years, interest has increased in using natural products for pharmacological purposes, as a form of complementary or replacement therapy. Particularly in the case of diabetes, published reports show that numerous extracts obtained from plants are effective in reducing glycemia, causing fewer side effects and with lower cost than the usual antidiabetic agents (Gupta et al., 2005).

The majority of the plants that are used in popular medicine for treatment of diabetes have been shown to possess biologically active chemical constituents (alkaloids, carbohydrates, cumarins, flavonoids, terpenoids, phenolic substances, and other constituents) that can be used as new hypoglycemiant agents (Marles, Farnsworth, 1995; Gupta et al., 2005; Negri, 2005).

Yacon is a plant native to the Andes, a species of the family Asteraceae (Compositae), with the botanical name Smallanthus sonchifolius. Morphologically, it is a perennial herb 1.5 to $3.0 \mathrm{~m}$ in height, with a root system composed of 4 to 20 oval or fusiform, fleshy tubers. The aerial part is formed by large leaves and flowers with yellow, radially arranged petals (Grau, Rea, 1997).

Several studies have shown that the leaves of this plant possess different biological effects, among them inhibition of migration of polymorphonuclear leucocytes (Schorr, 2005), immunomodulation (Lebeda et al., 2003; Valentová and Ulrichová, 2003), antioxidant, and cytoprotector (Valentová et al., 2005) effects. In addition, studies have reported that tea made from an infusion of yacon leaves reduces glycemia and increases the concentration of insulin in the plasma of diabetic rats (Aybar et al., 2001). Valentová et al. (2003, 2004) observed that a yacon extract reduced the proportion of glucose in cultures of hepatocytes, acting in a manner similar to insulin.

Phytochemical studies have demonstrated that yacon leaves and stems are rich in proteins and phenolic compounds, such as caffeine, chlorogenic acid, ferulic acid, and flavonoids such as quercetin (Valentová et al., 2003). The roots of the plant contain fructose, glucose, and fructooligosaccharides (inulin type), that can act as prebiotics, since after fermentation they favor the development of the bacterial flora (Pedreschi et al., 2003).

Considering the increasing use of yacon in popular medicine, the present series of studies evaluated the effect of crude extracts of yacon leaves, obtained in different ways, on glycemia in diabetic and nondiabetic animals. The acute toxicity of the extract and the effect of the treatment on the levels of creatinine and the activity of certain enzymes on the plasma of the animals were also evaluated.

\section{MATERIAL AND METHODS}

\section{Animals}

The experiments were done using male Wistar rats weighing 180 to $220 \mathrm{~g}$, and male and female Swiss mice weighing 20 to $25 \mathrm{~g}$. The animals were maintained in controlled temperature $\left( \pm 22^{\circ} \mathrm{C}\right)$ and a 12-hour dark-light cycle, with balanced food and free access to water. The protocol for these experiments was approved by the Committee on Experimental Animal Ethics of the State University of Maringá, under number 014/2003.

\section{Preparation of crude extracts}

The extracts were prepared in three forms, from yacon leaves acquired from Takashi Kakihara Ltda., Capão Bonito, São Paulo, collected in December 2003. A voucher specimen was deposited at the Herbarium of the University of Maringá under number HUEM 13021. The crude extracts were obtained from $10 \%(\mathrm{w} / \mathrm{w})$ solutions, by maceration with water at ambient temperature (cold extraction $-\mathrm{Y}_{\mathrm{C}}$ ) or by infusion in boiling water until the solution cooled (hot extraction $-\mathrm{Y}_{\mathrm{H}}$ ). The hydro-ethanolic extract $\left(\mathrm{Y}_{\mathrm{E}}\right)$ was obtained from a $10 \%(\mathrm{w} / \mathrm{w})$ solution with $70 \%$ ethanol, shaken mechanically for 5 hours. Next, the extracts were filtered, slowly evaporated to remove the solvent, lyophilized, and stored at $-20{ }^{\circ} \mathrm{C}$. For the assays, the extracts of yacon leaves were diluted in water immediately before use.

\section{Induction of diabetes}

Diabetes was induced in rats fasted for 15 hours by intraperitoneal injection of streptozotocin (STZ), $50 \mathrm{mg} / \mathrm{kg}$ body weight, dissolved in $0.1 \mathrm{M}$ citrate buffer ( $\mathrm{pH} 4.6$ ) (Brosky, Logothelopoulos, 1969). After 48 h, blood was collected from a small incision made at the distal extremity of the fed animal's tail, for determination of glycemia. Rats with glycemia above $250 \mathrm{mg} / \mathrm{dL}$ were included in the study.

\section{Treatment of animals}

The crude extracts of yacon leaves $(400 \mathrm{mg} / \mathrm{kg}$ body weight) or water were administered by the oral route (gavage), in a single daily dose at 9:00 $\mathrm{h}$ in the morning, in diabetic and nondiabetic rats. According to the experiment, the treatment was administered for different periods $(3,7$, 10 or 14 days). 


\section{Collection of blood}

At the end of the experimental period, the rats were fasted for $15 \mathrm{~h}$ and then anesthetized (ketamine and xylazine 1:1). Blood samples were collected from the inferior vena cava blood in heparinized tubes. The blood samples were centrifuged at $2500 \mathrm{rpm}$ for $10 \mathrm{~min}$, and the plasma was separated.

\section{Effect of the hydro-ethanolic extract of yacon on glucose and creatinine in the plasma}

The concentration of glucose was determined in aliquots of plasma $(10 \mu \mathrm{L})$, using the glucose-oxidase colorimetric enzyme method (Gold Analisa ${ }^{\circledR}$ ). The concentration of creatinine in the plasma was determined by a colorimetric enzyme method using Gold Analisa ${ }^{\circledR}$ commercial kits.

\section{Effect of hydro-ethanolic extract of yacon on consumption of food and water, volume of urine, and body weight of diabetic and nondiabetic rats}

Groups of diabetic and nondiabetic animals were maintained in metabolic cages for 14 days, under treatment with the hydro-ethanolic extract of yacon, or water. The consumption of food and water, volume of urine, and body weight of these animals were evaluated daily.

\section{Effect of hydro-ethanolic extract of yacon on the elevation of amylose-induced glycemia}

Groups of nondiabetic rats fasted for $15 \mathrm{~h}$ received acarbose (10 $\mathrm{mg} / \mathrm{kg}$ body weight), hydro-ethanolic extract of yacon $(400 \mathrm{mg} / \mathrm{kg})$, or water, and subsequently received, orally, a solution of amylose $(500 \mathrm{mg} / \mathrm{mL})$, at a dose of $1 \mathrm{~g} / \mathrm{kg}$ body weight. After $30 \mathrm{~min}$, their blood was collected for determination of glycemia (Galletto et al., 2004).

Effect of the hydro-ethanolic extract of yacon on the elevation of glucose-induced glycemia

Groups of non-diabetic rats fasted for $15 \mathrm{~h}$ received hydro-ethanolic extracts of yacon $(400 \mathrm{mg} / \mathrm{kg}$ body weight), or water, and then received orally, a solution of $50 \%$ glucose ( $1 \mathrm{~g} / \mathrm{kg}$ body weight). After $15,30,60$, and $120 \mathrm{~min}$, blood was collected for determination of glycemia (Zaahkouk et al., 2003).
Effect of hydro-ethanolic of yacon on the activity of plasma phosphatase and transaminases

The activity of alkaline phosphatase (ALP), aspartate aminotransferase (AST), and alanine aminotransferase (ALT) was determined in the plasma of diabetic and nondiabetic animals, by the colorimetric-kinetic method, using a commercial kit (Gold Analisa $\left.{ }^{\circledR}\right)$. The animals were orally treated with the hydro-ethanolic extract of yacon $\left(\mathrm{Y}_{\mathrm{E}}\right)$, at the dose of $400 \mathrm{mg} / \mathrm{kg}$, or with water, for 14 days. On day 15 , the animals, fasted for $15 \mathrm{~h}$, were anesthetized (ketamine and xylazine 1:1), for collection of blood which was used in the determinations.

\section{Acute toxicity $\left(\mathbf{L D}_{50}\right)$}

Male and female mice fasted were orally administered with the hydro-ethanolic extract of yacon. Doses were increased progressively for the determination of the Lethal Dose $\left(\mathrm{LD}_{50}\right)$. The animals $(\mathrm{n}=10)$ were observed for 7 days, following treatment; food and water were provided throughout the experiment.

\section{Statistical analysis}

The statistical analysis of the data was done using GraphPad Prism ${ }^{\circledR}$ (Graphpad Software Inc, Microsoft Corp.). The results were expressed as mean \pm standard error of the mean, and were analyzed using Student's $t$ test for comparison of two means, or analysis of variance (ANOVA followed by Tukey's test) for multiple comparisons. $\mathrm{P}<0.05$ was considered the criterion for significance.

\section{RESULTS} Effect of extracts of yacon $\left(\mathrm{Y}_{\mathrm{C}^{\prime}} \mathrm{Y}_{\mathrm{H}}\right.$ and $\left.\mathrm{Y}_{\mathrm{E}}\right)$ on glycemia
in diabetic and nondiabetic rats

The effect of the extracts of yacon $\left(\mathrm{Y}_{\mathrm{C}}, \mathrm{Y}_{\mathrm{H}}\right.$ and $\left.\mathrm{Y}_{\mathrm{E}}\right)$ on the glycemia of diabetic and nondiabetic rats fasted for $15 \mathrm{~h}$, treated orally for 14 days with a dose of $400 \mathrm{mg} / \mathrm{kg}$ body weight, is shown in Figure 1A and 1B.

The groups of nondiabetic rats treated with the aqueous extracts, extracted with cold water $\left(\mathrm{Y}_{\mathrm{C}}\right)$ or hot water $\left(\mathrm{Y}_{\mathrm{H}}\right)$, did not show a change in glycemia $\left(\mathrm{Y}_{\mathrm{C}}=\right.$ $111.3 \pm 4.9$ and $\left.\mathrm{Y}_{\mathrm{H}}=138.5 \pm 7.7 \mathrm{mg} / \mathrm{dL}\right)$ compared to the control group $(106.3 \pm 3.5 \mathrm{mg} / \mathrm{dL})$. However, treatment of the nondiabetic rats with the hydro-ethanolic extract $\left(\mathrm{Y}_{\mathrm{E}}\right)$ significantly reduced (28\%) the glycemia of the animals $\left(Y_{E}=76.1 \pm 6.7\right)$. The results are shown in Figure 1A. 


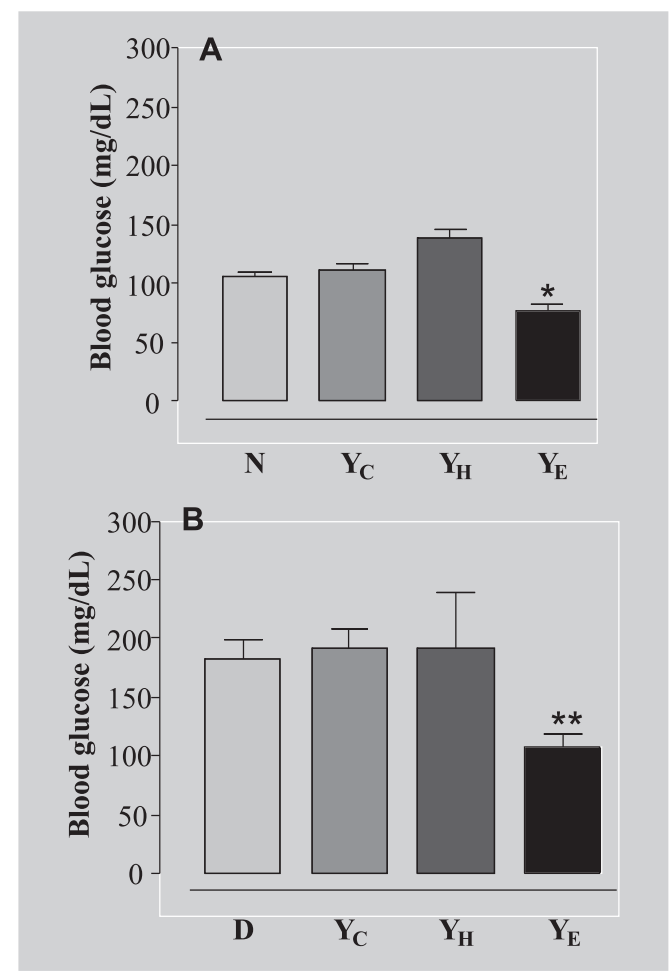

FIGURE 1 - Effect of crude extracts of yacon leaves on glycemia of nondiabetic rats (A) and diabetic rats (B) fasted for $15 \mathrm{~h}$. The animals were treated orally with the different extracts in a single daily dose ( $400 \mathrm{mg} / \mathrm{kg}$ body weight), for 14 days. $Y_{C}$ : aqueous extract of yacon leaves, cold extraction; $\mathrm{Y}_{\mathrm{H}}$ : aqueous extract of yacon leaves, hot extraction; $Y_{\mathrm{E}}$ : hydro-ethanolic extract of yacon. The results represent the mean \pm S.E.M. of 5-10 animals per group. $* \mathrm{P}<0.05$ compared to the control group of nondiabetic rats $(\mathrm{N}) ; * * \mathrm{p}<0.01$ compared to the control group of diabetic animals (D). (ANOVA followed by Tukey's test).

The glycemia of the diabetic rats was $182.9 \pm 15.4 \mathrm{mg} / \mathrm{dL}$, i.e., $72 \%$ higher than that of the nondiabetic rats (Figure 1B). Treatment of the diabetic animals with the $\mathrm{Y}_{\mathrm{C}}$ or $\mathrm{Y}_{\mathrm{H}}$ did not change the plasma glucose concentration $\left(\mathrm{Y}_{\mathrm{C}}=192.3 \pm 5.7\right.$ and $\left.\mathrm{Y}_{\mathrm{H}}=191.7 \pm 7.7 \mathrm{mg} / \mathrm{dL}\right)$. However, treatment with $\mathrm{Y}_{\mathrm{E}}$ significantly (59\%) reduced the glycemia of the diabetic rats $\left(\mathrm{Y}_{\mathrm{E}}=108.24 \pm 9.7\right)$, which reverted to normal levels (Figure $1 \mathrm{~B})$.

Considering that only the hydro-ethanolic extract of yacon, at the concentration used, was capable of reducing the glucose levels of the diabetic and nondiabetic animals, the subsequent experiments were performed using only $\mathrm{Y}_{\mathrm{E}}$.

Treatment of the diabetic and nondiabetic rats with $\mathrm{Y}_{\mathrm{E}}$, for different periods of time, showed that a significant reduction of glycemia occurred only in the 14-day treatment period. The results are shown in Figure 2A and 2B.

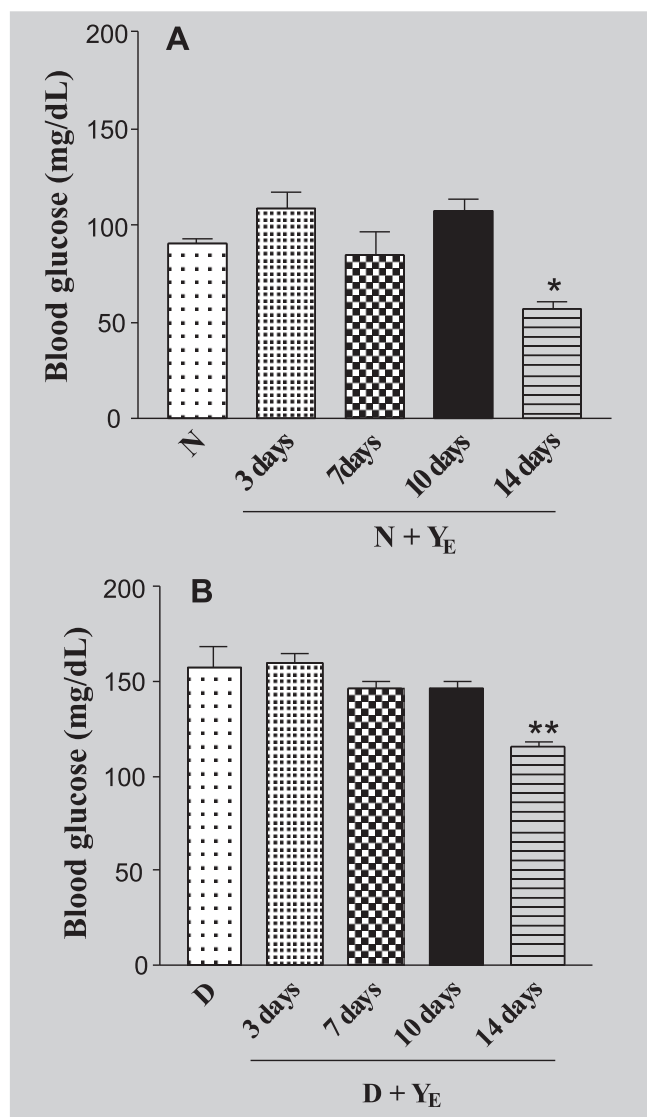

FIGURE 2 - Effect of hydro-ethanolic extract of yacon $\left(\mathrm{Y}_{\mathrm{E}}\right)$, administered orally at the dose of $400 \mathrm{mg} / \mathrm{kg}$ body weight, on the glycemia of nondiabetic rats (A) and diabetic rats (B) after different periods of treatment. The results represent the mean \pm S.E.M. of 5-10 animals per group. $* \mathrm{P}<0.05$ compared to the control group of nondiabetic rats $(\mathrm{N}) ; * * \mathrm{p}<0.01$ compared to the control group of diabetic animals (D). (ANOVA followed by Tukey's test).

\section{Effect of the hydro-ethanolic extract of yacon on the consumption of food and water, volume of urine, and body weight of diabetic and nondiabetic rats}

To investigate whether the reduction of glycemia observed in the previous experiment is related to lower food intake of the animals, an experiment was performed to evaluate the food consumption of diabetic and nondiabetic control rats, treated with $\mathrm{Y}_{\mathrm{E}}$. Simultaneously, the consumption of water, urine volume, and body weight of the animals, which were maintained in a metabolic cages for 14 days, were evaluated.

As shown in Table I and Figure 3, there were significant differences in all the parameters evaluated (consumption of water and food, urine volume, and weight gain) between the groups of diabetic (D) and nondiabetic 
TABLE I - Effect of the hydro-ethanolic extract of yacon $\left(\mathrm{Y}_{\mathrm{E}}\right)$, administered orally in a dose of $400 \mathrm{mg} / \mathrm{kg}$ body weight for 14 days, on the consumption of food and water, and volume of urine of diabetic and nondiabetic rats

\begin{tabular}{lccc}
\hline Group & Consumption of food $(\mathrm{g} / 100 \mathrm{~g}$ body weight $)$ & Consumption of water $(\mathrm{mL})$ & Urine volume $(\mathrm{mL})$ \\
\hline $\mathrm{N}$ & $10.1 \pm 0.3$ & $41.2 \pm 3.2$ & $8.0 \pm 1.6$ \\
$\mathrm{~N}+\mathrm{Y}_{\mathrm{E}}$ & $10.5 \pm 0.6$ & $39.3 \pm 2.4$ & $5.2 \pm 0.5$ \\
$\mathrm{D}$ & $13.5 \pm 0.9^{*}$ & $69.1 \pm 10.8^{*}$ & $29.7 \pm 7.8^{*}$ \\
$\mathrm{D}+\mathrm{Y}_{\mathrm{E}}$ & $14.3 \pm 0.9^{*}$ & $73.3 \pm 12.8^{*}$ & $29.6 \pm 9.1^{*}$ \\
\hline
\end{tabular}

Diabetic (D) and nondiabetic $(\mathrm{N})$ animals were maintained in metabolic cages for 14 days, under treatment with the hydroethanolic extract of yacon $\left(\mathrm{Y}_{\mathrm{E}}\right)$ or water. Each value represents the mean \pm S.E.M. of 6 animals per group. ${ }^{*} \mathrm{P}<0.05$ compared to the control group of nondiabetic rats $(\mathrm{N})$.

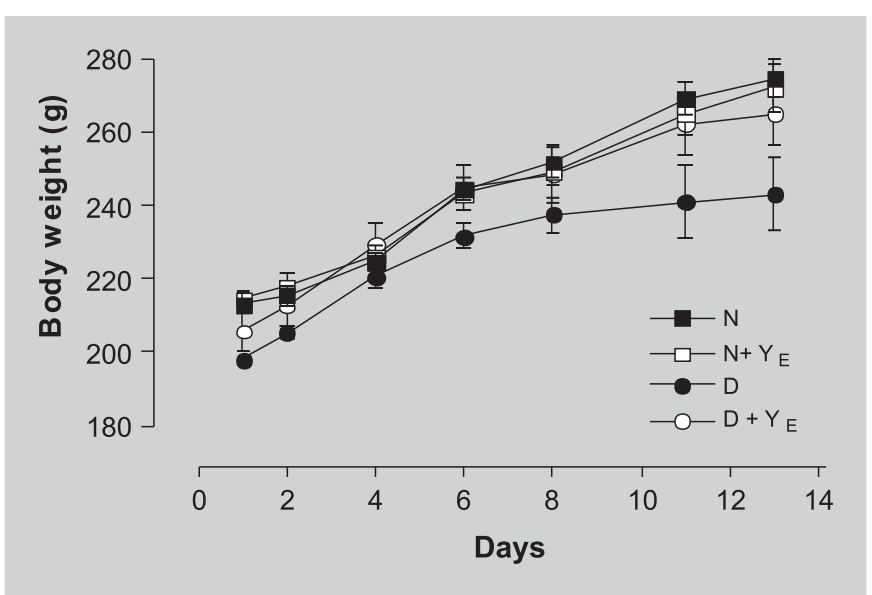

FIGURE 3 - Effect of the hydro-ethanolic extract of yacon $\left(\mathrm{Y}_{\mathrm{E}}\right)$, administered orally in a dose of $400 \mathrm{mg} / \mathrm{kg}$ body weight for 14 days, on the body weight of nondiabetic rats $(\mathrm{N})$ and diabetic rats (D). Each point represents the mean \pm S.E.M. of 6 animals per group.

(N) animals. The food consumption of the diabetic rats increased approximately $25 \%$, although these animals gained less weight (weight gain $=45.0 \mathrm{~g}$ ) compared to the group of nondiabetic animals (weight gain $=61.3 \mathrm{~g}$ ).

Treatment of the diabetic and nondiabetic animals with $Y_{E}$ did not change their consumption of food and water or the urine volume, compared to the respective groups of animals treated only with water (control). Nevertheless, treatment with the extract returned the weight gain of the diabetic rats (weight gain $=59.2 \mathrm{~g}$ ) to a level similar to the group of nondiabetic rats (weight gain $=57.3 \mathrm{~g}$ ). The results are shown in Figure 3.

\section{Effect of hydro-ethanolic extract of yacon on the elevation of glycemia induced by oral administration of amylose or glucose}

Another explanation for the reduction of plasma glucose levels, observed in the animals treated with the extract, is that there was interference in the intestinal absorption of carbohydrates. As shown in Figure 4, in contrast to the effect of acarbose, treatment of the nondiabetic animals with the extract did not inhibit the elevation of glucose levels caused by the amylose. The same was observed when the assays were done using a glucose solution instead of amylose (Figure 5).

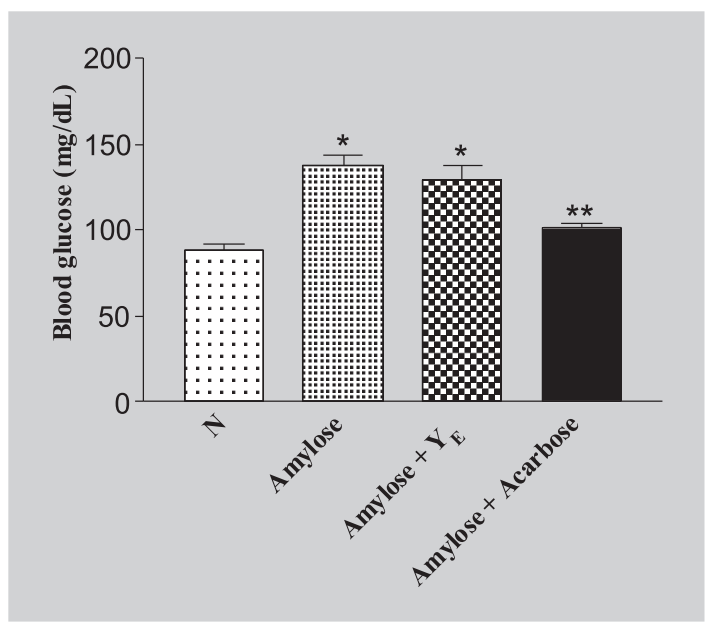

FIGURE 4 - Glycemia, after 30 minutes, of nondiabetic rats that received, orally, water $(\mathrm{N})$, amylose $(1 \mathrm{~g} / \mathrm{kg}$ body weight), amylose $(1 \mathrm{~g} / \mathrm{kg}$ body weight $)+\mathrm{Y}_{\mathrm{E}}(400 \mathrm{mg} / \mathrm{kg}$ body weight), or amylose ( $1 \mathrm{~g} / \mathrm{kg}$ body weight $)+$ acarbose (10 $\mathrm{mg} / \mathrm{kg}$ body weight). Each point represents the mean \pm S.E.M. of 5 animals per group. $* \mathrm{P}<0.05$ compared to the control group of nondiabetic rats $(\mathrm{N}) ; * \mathrm{*} p<0.05$ compared to the group of rats that received amylose (ANOVA followed by Tukey's test).

Effect of the hydro-ethanolic extract of yacon on the activity of transaminases and alkaline phosphatase in rat plasma

Figures $6 \mathrm{~A}, 6 \mathrm{~B}$, and $6 \mathrm{C}$ show the activity of AST, ALT, and ALP in the plasma of diabetic and nondiabetic 


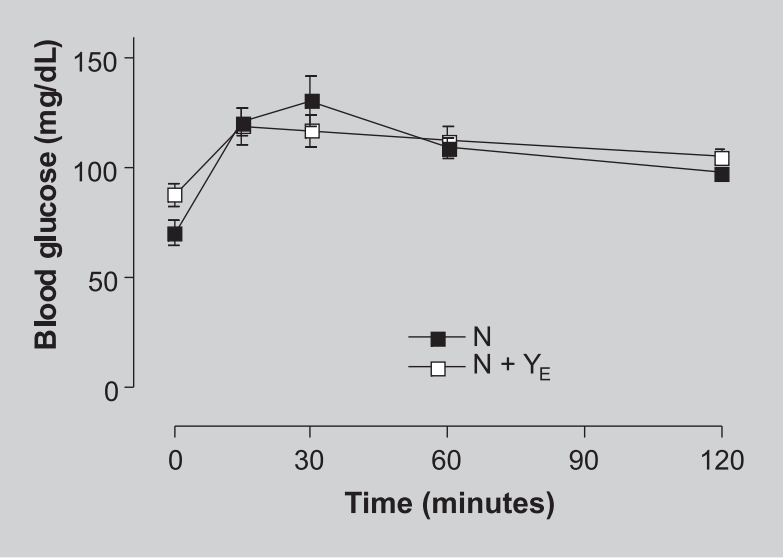

FIGURE 5 - Glycemia of nondiabetic rats that received orally, upload glucose $(1 \mathrm{~g} / \mathrm{kg}$ body weight $)+$ water $(\mathrm{N})$ or upload glucose $(1 \mathrm{~g} / \mathrm{kg}$ body weight $)+\mathrm{Y}_{\mathrm{E}}(400 \mathrm{mg} / \mathrm{kg}$ body weight $)\left(\mathrm{N}+\mathrm{Y}_{\mathrm{E}}\right)$. Each point represents the mean \pm S.E.M. of 6 animals per group.

rats. The activity of these enzymes was significantly increased in the plasma of the diabetic rats (D) compared to the nondiabetic rats $(\mathrm{N})$. The oral treatment of nondiabetic rats with the $\mathrm{Y}_{\mathrm{E}}$ for 14 days did not alter the activity of the enzymes. The treatment of the diabetic rats resulted in normalization of the activity of the enzymes AST, ALT, and ALP.

\section{Effect of the hydro-ethanolic extract of the yacon on plasma creatinine}

The concentration of creatinine in plasma was not altered in the diabetic rats compared to the nondiabetic rats. Oral administration of $Y_{E}$ in diabetic (D) and nondiabetic (N) rats for 14 days, did not change the concentration of plasma creatinine. The results are shown in Figure 6D.

\section{Acute toxicity of the hydro-ethanolic of yacon}

The acute toxicity of the hydro-ethanolic extract of yacon, administered orally, was low in the mice. No deaths or other adverse effects (change in behavior, posture, exploratory movements, convulsions, abdominal contortions) were observed at doses up to $5000 \mathrm{mg} / \mathrm{kg}$.

\section{DISCUSSION}

The present study investigated the effect of crude extracts of yacon leaves (aqueous/cold extraction- $Y_{C}$ and hot$\mathrm{Y}_{\mathrm{H}}$, and hydro-ethanolic - $\mathrm{Y}_{\mathrm{E}}$ ), on glycemia of fasting diabetic and non-diabetic rats. Streptozotocin - STZ ( $50 \mathrm{mg} / \mathrm{kg}$ body weight) administered intraperitoneally in rats, effectively

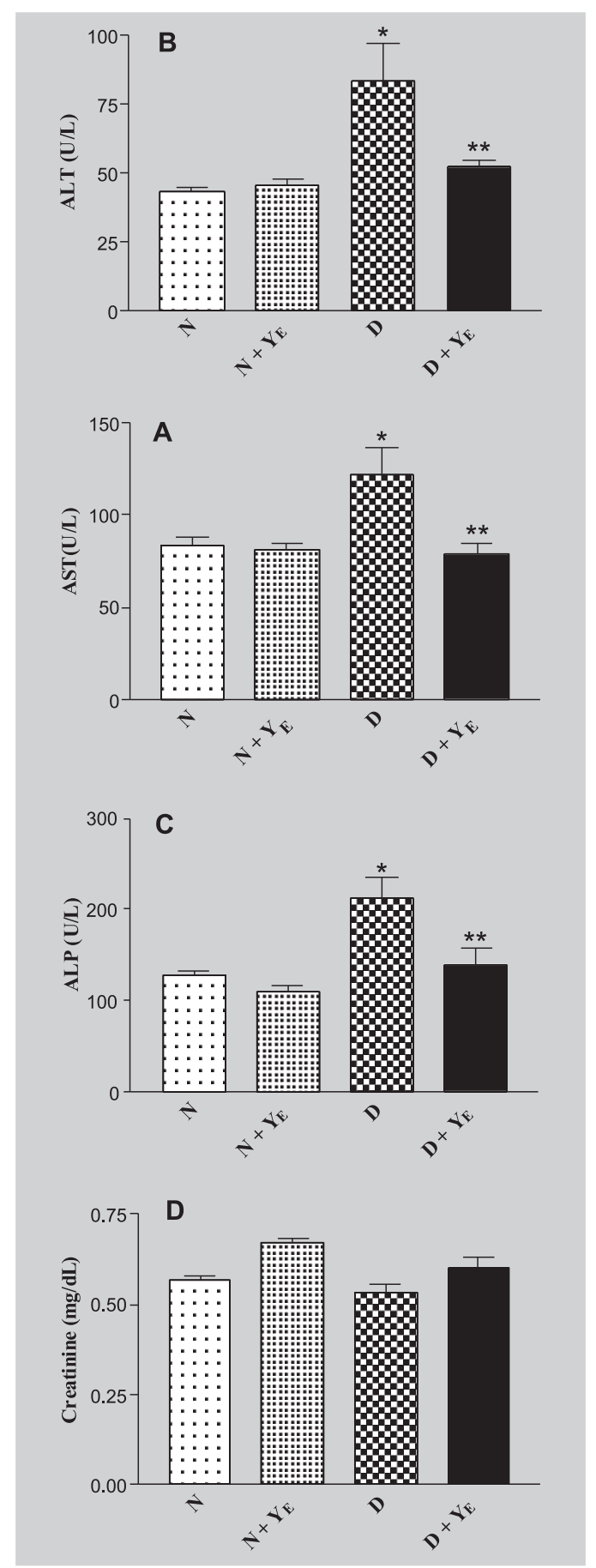

FIGURE 6 - Effect of the hydro-ethanolic extract of yacon on the activity of aspartate aminotransferase - AST (A), alanine aminotransferase - ALT (B), alkaline phosphatase - ALP (C) and creatinine (D) of nondiabetic rats $(\mathrm{N})$ and diabetic rats (D) fasted for 15 hours. The animals were treated with $Y_{E}$ for 14 days, orally, at the dose of $400 \mathrm{mg} / \mathrm{kg}$ body weight. Each bar represents the mean \pm S.E.M. of 6 animals. $* \mathrm{P}<0.05$ compared to the control group of nondiabetic rats. ${ }^{* *} \mathrm{P}<0.05$ compared to the control group of diabetic rats (ANOVA followed by Tukey's test). 
induced diabetes, as observed by the elevation of glycemia, polyphagy, polydipsia, and loss of body weight of the animals compared to nondiabetic rats.

The $\mathrm{Y}_{\mathrm{E}}$ administered orally at the dose of $400 \mathrm{mg} / \mathrm{kg}$ body weight for 14 days, significantly reduced the levels of blood glucose of the diabetic rats (59\%) and nondiabetic rats $(28 \%)$. This effect was not observed when the crude aqueous extracts of yacon $\left(\mathrm{Y}_{\mathrm{C}}\right.$ and $\left.\mathrm{Y}_{\mathrm{H}}\right)$, prepared in the same concentration (10\%), and administered in the same dosage were used.

These results complement those of Aybar et al. (2001), who observed that tea made from an infusion of yacon leaves, administered orally for 30 days, reduced glycemia in diabetic rats by about $27 \%$. According to these investigators, the inhibitory action of this preparation on STZ-induced hyperglycemia can be attributed to the fact of this plant induces an increase in the concentration of plasma insulin.

According to Simonovska et al. (2003), the solvent used in the preparation of plant extracts can qualitatively and/or quantitatively affect the biologically active chemical constituents extracted. Therefore, the results indicate that the form of preparation of the extract is very important for its biological activity, and that probably the active principles responsible for the effect of the extract obtained from yacon leaves on glycemia of rats are extracted better with an organic solvent.

It is important to emphasize that the effect of the extract on the glycemia of rats was only observed after 14 days of treatment, indicating that the actives substances requires a certain period of time to reach effective concentrations in the organism. Similar results were reported by other investigators, who observed that some plant extracts show hypoglycemiant activity only after a more prolonged period of administration (Mohammed-AliAjabnoor, 1990; Roman-Ramos, 1991; Alarcon-Aguilara, 1998; Aybar et al., 2001).

There are several possibility for the mechanisms by which the plant reduces blood glucose concentration: increased release of insulin through stimulation of the $\beta$ pancreatic cells, resistance to the hormones that increase the rate of glucose release, increase of the number and sensitivity of the insulin receptors, decreased release glycogen degradation, increase in glucose uptake by tissues and organs, and reduction of the intestinal absorption of glucose, among others (cited in the revision of Negri, 2005).

Although it is not possible to establish the exact mechanism of action of the $Y_{E}$ from the data of the present study, it was clearly demonstrated that the inhibitory effect on the hyperglycemia of diabetic rats is not related to reduction of food intake or to interference of the extract with the intestinal absorption of carbohydrates.

Additionally, it was observed that the activity of the transaminases (AST and ALT) and alkaline phosphatase (ALP) was increased in the plasma of the diabetic rats, which is consistent with the results of other investigators (Mori et al., 2003; Prakasam et al., 2004; Hwang et al., 2005). These manifestations are a consequence of a metabolic alteration, with an increase of glyconeogenesis and of cetogenesis and/or of hepatic lesions that occur in diabetic animals (Mori et al., 2003).

Treatment of the diabetic rats with the $Y_{E}$ reversed the activity of the enzymes AST, ALT, and ALP to values near to those of nondiabetic rats. One explanation for this is that treatment with the $\mathrm{Y}_{\mathrm{E}}$ may suppress the hepatocellular lesions induced by the disease itself, suggesting that the reduction of glycemia in the diabetic rats does not result from hepatic toxicity induced by the extract.

Finally, it must be considered that the diabetic animals treated with the $Y_{E}$ showed improvement in weight gain compared to the diabetic rats that did not receive the treatment. These data confirms the antidiabetogenic effect of the extract, since the diabetic state is associated with a lower weight gain, or loss of weight of the animals (Maiti et al., 2004).

Oral administration of $Y_{E}$ in doses up to $5000 \mathrm{mg} / \mathrm{kg}$ body weight did not cause acute toxicity in the animals, indicating that the margin of safety of this extract is quite high. Daily treatment with $\mathrm{Y}_{\mathrm{E}}$ at the dose of $400 \mathrm{mg} / \mathrm{kg}$ body weight, orally for 14 days, did not cause mortality or other signs of toxicity. Genta et al. (2005) described similar results, although they used an extract of yacon roots administered orally to the animals.

In summary, the present study provided evidence indicating that the hydro-ethanolic extract of yacon significantly reduces the levels of glucose in diabetic rats. In addition, treatment with the extract causes the recovery of certain altered biochemical parameters and of the body weight of diabetic animals. This being so, these results justify the development of additional pharmacological and biochemical studies in order to clarify the nature of the compounds responsible for the effect and the exact mechanism of action of these compounds.

\section{RESUMO}

\section{Efeito do extrato bruto das folhas de Smallanthus sonchifolius (yacon) sobre a glicemia de ratos diabéticos}

O presente estudo investigou o efeito do extrato bruto das folhas de yacon, obtido por extração a frio $\left(Y_{C}\right)$ ou a quente 
$\left(Y_{H}\right)$, ou por extração hidro-alcoólica $\left(Y_{E}\right)$, na glicemia de ratos diabéticos (induzidos por estreptozocina, $50 \mathrm{mg} / \mathrm{kg}$, i.p.) e não diabéticos. Os animais foram tratados por via oral com os extratos (400 $\mathrm{mg} / \mathrm{kg})$ ou água por um período de 3 , 7, 10 e 14 dias. Após o tratamento, os animais foram anestesiados e amostras de sangue foram coletadas para determinações dos níveis de glicose e creatinina plasmática e da atividade de enzimas (AST, ALT, ALP). Também foi avaliado o consumo de ração, água, volume de urina, peso corporal dos animais e a $D L_{50}$ do $Y_{E^{*}}$ O tratamento dos animais com $Y_{E}$ por 14 dias, reduziu a glicemia de ratos diabéticos e não diabéticos. Adicionalmente, o $Y_{E}$ restaurou a atividade das enzimas que estavam alteradas, e melhorou o ganho de peso dos animais diabéticos. Estes resultados demonstraram que a efetividade do extrato de yacon está relacionada ao método de preparação do extrato e ao tempo de tratamento dos animais. $O$ efeito do $Y_{E}$ na glicemia de ratos diabéticos não está relacionado à redução da ingesta ou a interferência do extrato na absorção intestinal de carboidratos.

UNITERMOS: Extrato aquoso. Antihiperglicêmico. Diabetes Mellitus. Extrato hidro-alcoólico. Smallanthus sonchifolius.

\section{ACKNOWLEDGEMENTS}

We gratefully acknowledge financial support received from the Coordenação de Aperfeiçoamento de Pessoal de Nível Superior (CAPES). We also thank Mr. Jailson Araújo Dantas and Mrs. Célia Regina Miranda for technical assistance.

\section{REFERENCES}

AYBAR, M.J.; RIERA, A.S.; GRAU, A.; SANCHES, S.S. Hypoglicemic effect of the water extract of Smallanthus sonchifolius (Yacon) leaves in normal and diabetic rats. $J$. Ethnopharmacol., Lausanne, v.74, p. 125-132, 2001.

ALARCON-AGUILARA, F.J.; ROMAN-RAMOS, R.; PEREZ-GUTIERREZ, S.; AGUILAR-CONTRERAS, A.; CONTRERAS-WEBER, C.C.; FLORES-SAENZ, J.L. Study of the anti-hiperglicemic effect of plants used as antidiabetics. J. Ethnopharmacol., Lausanne, v. 61, p. 101-110, 1998.

BROSKY, G.; LOGOTHELOPOULOS, J. Streptozotocin diabetes in the mouse and guinea pig. Diabetes, New York, v. 18 , p. 606- 609, 1969.
FONTES, C.F.L. Diabetes. In: POIAN, A. T., CARVALHOALVES, P. C., (Ed.). Hormônios e metabolismo: Integração e correlações clínicas. Ed. Atheneu: São Paulo, p. 350, 2002.

GALLETTO, R.; SIQUEIRA, V.L.D.; FERREIRA, E.D.; OLIVEIRA, A.J.B.; BAZOTTE, R.B. Absence of antidiabetic and hypolipidemic effect of Gymnema sylvestre in non-diabetic and alloxan-diabetic rats. Braz. Arch. Biol. Technol., Curitiba, v. 47, p. 545-551, 2004.

GENTA, S.B.; CABRERA, W.M.; GRAU, A.; SANCHEZ, S.S. Subcronic 4-month oral toxicity study of dried Smallanthus sonchifolius (yacon) roots as a diet supplement in rats. Food Chem. Toxicol., Oxford, v.43, n.11, p.1657-1665, 2005.

GRAU, A.; REA, J. Smallanthus sonchifolius (Poepp. and Endl.) H. Robinson. In: Andean roots and tubers: Ahipa, arracua, maca and yacon. Promoting the conservation and use of underutilized and neglected crops, 21. Institute of Plants Genetics and Crop Plant Research, Gatersleben/ International Plant Genetic resources Institute, p. 199-242, 1997.

GUPTA, R.K.; KESARI, A.N.; MURTHY, P.S.; CHANDRA, R.; TANDON, V.; WATAL, G. Hypoglycemic and antidiabetic effect of ethanolic extract of leaves of Annona squamosa L. in experimental animals. J. Ethnopharmacol., Lausanne, v. 99, p. 75-81, 2005.

HWANG, H.J.; KIM, S.W.; LIM, J.M.; JOO, J.H.; KIM, H.O.; KIM, K.M.; YUN, J.W. Hypoglicemic effect of crude exopolysaccharides produced by a medicinal mushroom Phellinus baumii in streptozotocin-induced diabetic rats. Life Sci., New York, v. 76, p. 3069-3080, 2005.

JIN, D.Q.; LI, G.; KIM, J.S.; YONG, C.S.; KIM JA; HUH, K. Preventive effects of Laminaria japonica aqueous extract on the oxidative stress and xantine oxidase activity in streptozotocin-induced diabetic rat liver. Biol. and Pharm. Bull., Tokyo, v. 27, p. 1037-1040, 2004.

LEBEDA, A.; DOLEZAVOLA, L.; VALENTOVÁ, K.; DZIECHCARKAVA, M.; GLEPLOVA, M.; OPATOVÁ, H.; ULRICHOVA, J. Biological and chemical variability of maca and yacon. Chem. Listy, Praha, v. 97, p. 548-556, 2003. 
MAITI, R.; JANA, D.; DAS, U.K.; GHOSH, D. Antidiabetic effect of aqueous extract of seed of Tamarindus indica in streptozotocin-induced diabetic rats. J. Ethnopharmacol., Lausanne, v.92, p.85-91, 2004.

MARITIM, A.C.; SANDERS, R.A.; WATKINS III, J.B. Diabetes, oxidative stress, and antioxidants: a rewiew. $J$. Biochem. Mol. Toxicol., New York, v.17, p. 24-38, 2003.

MARLES, R.F.; FANSWORTH, N.R. Antidiabetic plants and their active constituents. Phytomedicine, Stuttgart, v.2, p.137-189, 1995.

MOHAMMED-ALI-AJABNOOR. Effect of aloes on blood glucose levels in normal and alloxan-diabetic mice. $J$. Ethnopharmacol., Lausanne, v.28, p. 215-220, 1990.

MORI, D.M.; BAVIERA, A.M.; DE OLIVEIRA RAMALHO, L.T.; VENDRAMINI, R.C.; BRUNETTI, I.L.; PEPATO, M.T. Temporal response pattern of biochemical analytes in experimental diabetes. Biotechnol. Appl. Biochem., San Diego, v.38, p.183-191, 2003.

NEGRI, G. Diabetes melito: plantas e princípios ativos naturais hipoglicemiantes. Rev. Bras. Cienc. Farm., São Paulo, v.41, p.121-142, 2005.

ORHAN, D.D.; ASLAN, M.; SENDOGDU, N.; ERGUN, F.; YESILADA, E. Evaluation of the hypoglycemic effect and antioxidant activity of three Viscum album subspecies (European mistletoe) in streptozotocin-diabetic rats. $J$. Ethnopharmacol., Lausanne, v.98, p.95-102, 2005.

PEDRESCHI, R.; CAMPOS, D.; NORATTO, G.; CHIRINOS, R.; CISNEROS-ZEVALLOS, L. Andean yacon roots (Smallanthus sonchifolius, Poepp. Endl) frutooligossaccharides as a potencial novel source of prebiotics. J. Agr. Food Chem., Baltimore, v.51, p.52785284, 2003.

PRINCE, P.S.M.; MENON, V.P. Antioxidant action of Tinospora cordifolia root extract in alloxan diabetic rats. Phytother. Res., London, v.15, p. 213-218, 2001.

PRAKASAM, A.; SETHUPATHY, S.; PUGALENDI, K.V. Influence of Casearia esculenta root extract on protein metabolism and marker enzymes in streptozotocininduced diabetic rats. Polish J. Pharmacol., Krakow, v.56, p.587-593, 2004.
RAJASEKARAN, S.; SIVAGNANAM, K.; SUBRAMANIAN, S. Antioxidant effect of Aloe vera gel extract in streptozotocin-induced diabetes in rats. Pharmacol. Rep., Krakow, v.57, p.90-96, 2005.

ROMAN-RAMOS, R.; FLORES-SAENZ, J.L.; PARTIDAHERNANDEZ, G.; LARA-LEMUS, A.; ALARCONAGUILAR, F. Experimental study of the hipoglycemic effect of some antidiabetic plants. Archi. Inv. Med., México, v.22, p.87-93, 1991.

SÁNCHEZ-MORENO, C.; LARRAURI, J.A.; SAURACALIXTO, F.A. A procedure to measure the antiradical efficiency of polyphenols. J. Sci. Food Agr., London, v.76, p.270-276, 1998.

SCHORR, K. Smallanthus sonchifolius (Asteraceae) estudo fitoquímico, controle de qualidade e ensaios biológicos. Ribeirão Preto, 2005. 263p. [Tese de doutorado. Faculdade de Filosofia, Ciências e Letras de Ribeirão Preto. Universidade de São Paulo].

SIMONOVSKA, B.; VOVK, I.; ANDRENSEK, S.; VALENTOVÁ, K.; ULRICHOVÁ, J. Investigation of phenolic acids in yacon (Smallanthus sonchifolius) leaves and tubers. J. Chromatogr. A, Amsterdam, v. 1016, p. 8998, 2003.

STADLER, K.; JENEI, V.; BÖLCSHAZY, G.V.; SOMOGYI, A.; JAKUS, J. Increased nitric oxide levels as an early sign of premature aging in diabetes. Free. Rad. Biol. Med., Oxford, v.35, p.1240-1251, 2003.

VALENTOVÁ, K.; ULRICHOVÁ, J. Smallanthus sonchifolius and Lepidium meyenii-Prospective Andean Crops for the prevention of chronic diseases. Biomed. Papers, Olomouc, v.147, p.119-130, 2003.

VALENTOVÁ, K.; CVAK, L.; MUCK, A.; ULRICHOVA, J.; SIMANCJ, V. Antioxidant effect of extracts from de leaves of Smallanthus sonchifolius. Eur. Nutr. J., Salem, v.47, p.61-65, 2003.

VALENTOVÁ, K.; MONCION, A.; WAZIER, I.; ULRICHOVA, J. The effect of Smallanthus sonchifolius leaf extract on rat hepatic metabolism. Cell Biol. Toxicol., London, v.20, p.109-120, 2004. 
VALENTOVÁ, K.; SERSEN, I.; ULRICHOVÁ, J. Radical scavenging and anti lipoperoxidative activities of Smallanthus sonchifolius leaf extracts. J. Agr. Food Chem., Washington, S3, p. 5571-5582, 2005.
ZAAHKOUK, S.A.M.; RASHID, S.Z.A.; MATTAR, A.F. Anti-diabetic properties of water and ethanolic extracts of Balanites aegyptiaca fruits flesh in senile diabetic rats. Egyptian J. Hosp. Med., Cairo, v. 10, p. 90-108, 2003.

Recebido para publicação em 05 de novembro de 2007 Aceito para publicação em 24 de junho de 2008 